Wim J. Wolff

\title{
The exploitation of living resources in the Dutch Wadden Sea: a historical overview
}

Received: 5 July 2004/ Revised: 5 September 2004 / Accepted: 6 September 2004 / Published online: 18 January 2005 (c) Springer-Verlag and AWI 2005

\begin{abstract}
An overview, based on written sources and personal observations, is presented of exploitation of living resources in and around the Dutch Wadden Sea during the past few centuries. It is concluded that before about 1900 exploitation was almost unrestricted. Exploitation of plants has been documented for saltmarshes and eelgrass beds. Fisheries have occurred for two species of hydroids, two species of polychaetes, one echinoderm species, at least seven species of molluscs, three species of crustaceans, and tens of species of fish. Hunting and egg collecting targeted almost all species of birds. Finally, two species of seals were exploited: information on exploitation of cetaceans is not available. Hence, it is likely that overexploitation may have been involved in the extirpation of several species. This supports an earlier suggestion that overexploitation played a part in the disappearance of at least 17 species from the Dutch Wadden Sea. This conclusion is confirmed by the observation that several extirpated species have returned after protective measures were introduced for the Dutch Wadden Sea area.
\end{abstract}

Keywords Overexploitation · Extinction · Fishing · Hunting $\cdot$ Harvesting

\section{Introduction}

Earlier, I analysed the causes of local extinctions or extirpations from the Dutch Wadden Sea (Wolff 2000a, 2000b). I identified 42 species that had disappeared in

Communicated by H.K. Lotze and K. Reise

W. J. Wolff

Department of Marine Biology, University of Groningen, P.O Box 14, 9750, AA Haren, The Netherlands

E-mail: W.J.Wolff@rug.nl

Tel.: + 31-50-3632260

Fax: $+31-50-3632261$ the past 2,000 years: at least 10 species of algae, 10 invertebrates, 13 fish, five birds and four marine mammals. Habitat destruction played a part in at least 26 cases, overexploitation in probably 17 cases, and in at least three cases pollution was involved. Two species disappeared due to unknown causes. The introduction of exotic marine species was not involved in any of the extirpation cases.

So, habitat destruction and overexploitation stand out as the most important causes of disappearance of species from the Dutch Wadden Sea. The importance of habitat change and destruction is immediately clear if one considers the long history of embankments and reclamations (Wolff 1992). But what evidence do we have that overexploitation might have been occurring on a major scale? In my earlier papers, I started by considering the disappeared species and looked for explanations for their disappearance. In this paper, I start with human activities, in particular exploitation of living resources, to see if they may have led to extirpations. This review, therefore, attempts to give an overview of the many forms of exploitation of living resources that have been, or still are, practised in the Dutch Wadden Sea area.

It will become clear that almost any living resource could be exploited. Overexploitation, however, is more difficult to demonstrate: most assumed cases rest on circumstantial evidence. In this paper, overexploitation is defined as the removal of plants or animals by collecting, hunting or fishing on such a scale that the number removed plus mortality from other causes is larger than the number of new individuals resulting from reproduction.

This paper concentrates on the Dutch Wadden Sea, including the barrier islands. I do not discuss fisheries in the North Sea off the barrier islands, although I am aware that for some species (e.g. cetaceans, some birds) a larger area should be considered to demonstrate the effects of exploitation.

During most of its history, the exploitation of this area was carried out by farmers and fishermen who were 
unable to document their activities. Hence, I also use information from other parts of the Dutch coast and from the German Wadden Sea.

\section{Overview of exploitation practices}

\section{Eelgrass}

The eelgrass Zostera marina used to occur in the westernmost part of the Dutch Wadden Sea, especially in large subtidal beds. Even in the thirteenth century, eelgrass was used as construction material for seawalls around this part of the Wadden Sea (Oudemans et al. 1870). Weijdt (1980) records that the use of eelgrass for dike-building ended around 1825 . According to the same author, $1 \mathrm{~m}$ of sea-wall required about $20 \mathrm{~m}^{3}$ of compacted eelgrass for construction, but Van der Vlis (1975) mentions $8 \mathrm{~m}^{3}$. This equals about $40-100 \mathrm{~m}^{3}$ of fresh eelgrass. The top layer of the eelgrass cover of the seawall had to be replaced every 2-3 years. Regulations from the local water boards demanded that fresh eelgrass had to be used, implying that people had to harvest the eelgrass beds. Although the construction of seawalls in the westernmost part of the Wadden Sea will have been a gradual process lasting centuries, Van der Vlis (1975) and Weijdt's (1980) figures show that huge quantities of eelgrass will have been involved. An order-ofmagnitude calculation, based on the area of eelgrass beds shown on the map in Oudemans et al. (1870) $\left(150 \mathrm{~km}^{2}\right)$, shows that in some years $1-10 \%$ of the annual production may have been involved. Major eelgrass occurrences are not known from the eastern part of the Dutch Wadden Sea, explaining why eelgrass was not used in dike-building in this area.

After 1826, eelgrass formed the basis for another human activity. The plants were collected from the beaches, or fished or mown by many fishing vessels. At the shore, the eelgrass was rinsed in freshwater, dried and used as roofing and insulation material, as well as to fill mattresses and cushions (Van der Vlis 1975; Van Katwijk 2003). This industry lasted until the seagrass beds in the western Wadden Sea disappeared around 1930 due to a wasting disease and the effects of a largescale engineering project ('Afsluitdijk') (Van Katwijk 2003).

\section{Saltmarshes}

Saltmarshes have been used as livestock grazing areas and for hay making for thousands of years. Until the twentieth century, almost all saltmarshes in the entire Dutch Wadden Sea were used for grazing or making hay. Even the isolated, tiny island of Griend was exploited: the right to make hay on this island was sold in 1916 to a nature conservation organisation (Gorter 1986). Nowadays, most of the marshes are managed by conservation organisations. This results in part of the marshes being unexploited, whereas other parts are still grazed, mainly by cattle, for conservation purposes. Also, the remaining farmers still graze cattle or sheep on their marshes.

For the Dutch Wadden Sea, no references have been found to human collection of saltmarsh plants for food. Locally, however, Salicornia spp. has been collected for use as a vegetable (K.S. Dijkema, personal communication). Apparently this never reached the scale observed in the SW Netherlands (Wolff, unpublished observations), where this used to be common practice for Salicornia spp. and Aster tripolium. In the twentieth century, Limonium vulgare was collected on a small scale for decoration (Wolff, unpublished observations).

\section{Hydroids}

Starting in 1896, a small fishery for hydroids developed. The species Sertularia cupressina and Hydrallmania falcata were fished for decorative purposes. The fished material was dried and dyed to be exported to Germany. In 1915, about 12.5 tons of hydroids were caught. The fishery ceased around the time of the Second World War (Vervoort 1946). German fishermen fished briefly for hydroids in the Ems estuary in 1955-1956 (Kirchhoff 2000).

\section{Polychaetes}

Two species of polychaetes are exploited to be sold as bait for sports fishermen: the lugworm Arenicola marina and the ragworm Nereis virens.

The picture of these forms of exploitation in the Dutch Wadden Sea is incomplete and is mainly based on the data for one year when Dijksterhuis (1977) collected some information on manual lugworm harvesting on the tidal flats near Den Helder and Texel. In 1977, 22 fulltime and 12 part-time professional lugworm diggers were active in this area. One person could harvest 2,000 3,000 worms per low-tide period. Annually, these people harvested about 16 million Arenicola. In addition, sports fishermen themselves dug another 600,000 lugworms per year.

In addition to manual harvesting, there is also mechanical harvesting in the same area. Four vessels dredge lugworms, and according to Van den Heiligenberg (1987) these vessels caught 18 million lugworms in 1977.

Although these figures may seem large, the manual diggers and the mechanical dredgers took only about $1 \%$ of the lugworms (density 17 individuals per $\mathrm{m}^{2}$; Beukema 1976) in 1977 at the tidal flats of the Marsdiep tidal basin $\left(110 \mathrm{~km}^{2}\right)$. Recovery of the other benthic fauna damaged by the diggers seems to proceed fairly quickly (Van den Heiligenberg 1987). 
There is even less information on digging of $N$. virens. This large polychaete is especially common in intertidal mussel beds that are illegally dug over. The scale of this human activity does not seem to be large.

\section{Molluscs}

In the first half of the twentieth century, five species of molluscs were exploited commercially in the Dutch Wadden Sea: the periwinkle Littorina littorea, the whelk Buccinum undatum, the European flat oyster Ostrea edulis, the blue mussel Mytilus edulis, and the cockle Cerastoderma edule. After 1980, a small fishery developed for the introduced American razor clam Ensis directus. Until now, the introduced Pacific oyster Crassostrea gigas has only been exploited in the Dutch Wadden Sea on a very small scale (N. Dankers, personal communication). Unlike the situation in North America, the soft-shelled clam Mya arenaria is not exploited; this constitutes the only example in the Wadden Sea of a large and common molluse species which is not exploited.

Periwinkles (L. littorea) were still caught for food in the 1970s: in the period 1960-1966 the annual catch was 13-32 tons fresh weight per year; after 1966 the catch strongly declined (Postuma and Rauck 1979).

Also whelks (B. undatum) were caught for food until about 1970: in the period 1949-1952 the average landings amounted to 65 tons per year and in 1960-1969 the annual catch was 17-60 tons fresh weight per year (Postuma and Rauck 1979; De Jonge et al. 1993).

The European flat oyster (O. edulis) is known to have occurred in several beds in the Dutch Wadden Sea between Texel and Wieringen, and near Terschelling and Schiermonnikoog since about 1700 (Van Benthem Jutting 1943). Archaeological traces of earlier exploitation have probably been lost due to rising sea levels. Dijt (1961) and Van der Vlis (1975) have described the former oyster fisheries between Texel and Wieringen. These fisheries date back to at least 1700 and flourished during the eighteenth century, when millions of oysters were caught annually. For example, in 176560 vessels from Texel, and also 60 vessels from Schiermonnikoog and 25 vessels from Zoutkamp fished these beds. The catch was sold in large cities such as Amsterdam and Hamburg. To be profitable, a vessel had to collect over 100,000 oysters per year. In the nineteenth century catches declined, and this became more serious early in the twentieth century. In the 1930s, the Texel oyster fishery came to an end. The last flat oysters were observed in the Wadden Sea around 1950. It has been suggested that the closure of the Zuiderzee in 1932 was also involved in the disappearance of the oyster beds (Dijkema 1997). The changed hydrographical conditions due to the building of this dam may have caused a larger loss of oyster larvae from the Wadden Sea to the North Sea.

The blue mussel (M. edulis) has probably been collected and fished in the Dutch Wadden Sea since time immemorial. However, Van der Vlis (1975) states that until the third quarter of the nineteenth century Texel fishermen did not harvest mussels, because they were considered a very low-quality food. This changed when, in the period 1873-1887, Wadden Sea fishermen could export 7,000 tons fresh weight of mussels to England annually. Also, after about 1865 mussel culture developed in the SW Netherlands; from the very beginning most of the seed mussels required for this culture were obtained from the Wadden Sea (Dijkema 1997). During the First World War, fishery for consumption mussels gained importance (in 1918 as many as 40,000 tons of mussels were sold), but after this war mussels were fished for feed for duck farms and for fertilising arable fields (Van der Vlis 1975). Only after a parasite (Mytilicola intestinalis) decimated the cultures in the SW Netherlands, mussel culture was introduced in the Dutch Wadden Sea in 1950. Up to now, this has been a thriving culture in the western part of the Dutch Wadden Sea in which about 75 vessels take part. This culture is based on seed mussels fished in the Wadden Sea to stock culture lots; annually up to 65,000 tons fresh weight may be caught (Ens 2003). However, there are not always sufficient seed mussels available. Especially after mild winters, spatfall of mussels is negligible. In the period 1988-1990, with three mild winters in a row, this led to a shortage of seed mussels and, consequently, the fishing away of almost all intertidal mussel beds in the Wadden Sea to stock the culture lots. Recovery of these beds took almost 10 years (Ens et al. 2004).

The cockle $(C$. edule $)$ was probably gathered with rakes for many centuries. In the 1960s, however, a mechanised fishery developed which subsequently developed into hydraulic suction dredging (Ens 2003). The manual gathering before 1960 produced about 1,000 2,000 tons fresh weight of cockles per year. The mechanised fisheries, however, became increasingly efficient and peaked at nearly 80,000 tons in 1989. The same series of mild winters that impacted the mussel industry also had an effect on cockle fisheries. In the Dutch Wadden Sea cockles also experienced an all-time low after the mild winters in 1988-1990, leading to new management rules. These rules included closed areas in locations where mussel beds or eelgrass beds might develop and a policy to reserve sufficient food for shorebirds in years with low cockle stocks. Since these rules proved to be partly unsuccessful, the Dutch government has proposed terminating all mechanised cockle fisheries in 2005 .

\section{Crustaceans}

Three species of crustaceans have been fished in the Dutch Wadden Sea: lobster (Homarus gammarus), edible crab (Cancer pagurus) and brown shrimp (Crangon crangon).

The common lobster ( $H$. gammarus) used to occur in Marsdiep tidal inlet near Den Helder (Holthuis 1950). It 
was caught in local fisheries but it is unclear if overexploitation was the cause of its disappearance. This apparently isolated, small population (the nearest other populations are found in the SW Netherlands and around Helgoland, Germany) may have died out due to natural environmental variation.

The edible crab (C. pagurus) also occurs in the tidal inlets of the Wadden Sea. Small numbers sometimes turn up in the fisheries statistics; in the SW Netherlands it is a commonly caught species.

The brown shrimp (C. crangon) is the subject of a large-scale fishery. Shrimp fishing is first mentioned by Coenen (1585) who records that he bought a squid from a shrimp fisher operating off the Dutch coast near Scheveningen in 1566. No doubt, shrimp fishing has continued uninterrupted until today. In the first half of the twentieth century, juvenile shrimps were dried and used as chicken feed. In the period 1960-1970 annual yields of immature shrimps for this purpose ranged from 1,200 to nearly 11,000 tons fresh weight. This practice was banned by the Dutch government around 1970 (Postuma and Rauck 1979). Nowadays, shrimps are a human delicacy. About 90 vessels have licences to fish for shrimp inside the Wadden Sea and in the North Sea off the barrier islands.

\section{Echinoderms}

Starfish (Asterias rubens) have been fished to be used as fertiliser on arable fields (Engel 1932). Postuma and Rauck (1979) report catches from the Dutch Wadden Sea of 149-2,000 tons per year. The importance of this fertiliser can be estimated from the fact that a scientific paper was even written on the quality of starfish fertiliser (De Ruyter de Wildt 1928). Nowadays, starfish are not exploited.

\section{Fish}

There exist very few species of fish in the Wadden Sea which have not been fished. Even non-target species, such as pipefish or gobies, turn up as bycatch and usually die on the fishing vessel. In former centuries, fishers operating on the Wadden Sea were numerous and they caught a large variety of species. Nowadays, only a few Wadden Sea fishermen are left; most fish is caught as bycatch by shrimpers.

Van Giffen (1913) showed that the coastal population of the Dutch Wadden Sea area about 2,000 years ago was able to catch cod (Gadus morrhua) and flounder (Platichthys flesus). More extensive archaeological data are presented by Brinkhuizen (1988, 1989). He showed that in the same period a wide variety of anadromous, estuarine and marine fish species were caught. The anadromous species included sturgeon (Acipenser sturio), twaite shad (Alosa fallax), allis shad (Alosa alosa) and salmon (Salmo salar) or sea trout (S. trutta). Among the estuarine and marine species, especially cod, mullets (Chelon labrosus, Liza ramada and/or L. aurata) and flatfish (flounder P. flesus, plaice Pleuronectes platessa, dab Limanda limanda and turbot Scophthalmus maximus) were numerous, whereas pelagic species were rare. Two observations of the meagre (Argyrosoma regius) are particularly remarkable.

In historical times, the centre of gravity of the Dutch Wadden Sea fisheries was found in the former Zuiderzee. This $3,800-\mathrm{km}^{2}$ brackish bay was separated from the western Dutch Wadden Sea by a dam in 1932 and subsequently changed into a freshwater lake (IJsselmeer). The Zuiderzee was ecologically different from the Wadden Sea proper. It had only a small tidal range, few tidal flats, and mostly mesohaline brackish water. This character was reflected in the fish species present. The major species were eel (Anguilla anguilla), smelt (Osmerus eperlanus), flounder (P. flesus), a local race of the herring (Clupea harengus) and anchovy (Engraulis encrasicholus). Eel and flounder were fished all year round, but herring and anchovy were caught only in spring and summer when they migrated into the Zuiderzee for spawning. In the twentieth century up to 1932 , eel catches usually remained below 1,000 tons per year, whereas flounder catches fluctuated around 1,000 tons annually. Smelt amounted to $1,000-1,500$ tons per year. Anchovy catches fluctuated strongly: in 1931 more than 4,000 tons were caught. The herring catch used to fluctuate around 10,000 tons per year. The loss of its spawning grounds in 1932 led to the nearly complete disappearance of the herring a few years later (Havinga 1954; Schaper 1962).

About 2,000 vessels, of which about 1,550 were larger than 5 tons, were employed in the Zuiderzee fisheries in 1920 (Schaper 1962). These fisheries ended in 1932 when the Zuiderzee was turned into a freshwater lake. Some of the fishermen was compensated by the Dutch government and started new jobs. Others started to catch freshwater fish, notably eel and pike-perch (Stizostedion lucioperca) (Havinga 1954; Schaper 1962). A third group of fishermen, especially those from the northern fishing villages and from Urk, continued to fish in the Wadden Sea and the North Sea.

Only very few Wadden Sea fish species spend their entire life in the Wadden Sea. Most species migrate for spawning either to the North Sea or to the rivers discharging into the Wadden Sea area. Of course, these species are also subject to exploitation in these areas.

The anadromous species, such as sturgeon, allis shad, twaite shad, houting (Coregonus oxyrinchus), salmon, sea trout, lamprey (Petromyzon marinus) and lampern (Lampetra fluviatilis), have strongly decreased or even gone extinct in the Wadden Sea. This is mainly because of human activities in the rivers. In various combinations, overfishing in the rivers, water pollution and river engineering works have resulted in the anadromous species becoming rare or extinct. This process started several centuries ago and culminated in the first half of the twentieth century (De Groot 1990a, 1990b, 1992a, 1992b). 
On the other hand, bottom trawling in the North Sea has led to a marked decrease in many demersal species, especially the slowly reproducing, long-lived species (De Vooys et al. 1991). Since the majority of Wadden Sea fish species migrate between this area and the North Sea (Zijlstra 1979), this decline is also observed in the Wadden Sea. Species like the thornback ray (Raja clavata), the sting ray (Dasyatis pastinacea) and several species of small sharks have disappeared from the Wadden Sea (Wolff 2000a, 2000b).

Birds

Nowadays, only a very limited number of bird species occurring in the Wadden Sea still have an open hunting season in the Netherlands. This situation evolved from 1880 when "useful" species of birds got legal protection. In 1912, more species were included and another step in protection was made in 1936 (Gorter 1986).

A seventeenth century manuscript (Anonymous 1636) kept in the Royal Library at The Hague provides a picture of earlier centuries. This manuscript describes the hunting trade in the Dutch province of Holland, in particular the surroundings of The Hague and the Rhine-Meuse estuary, in the early years of the seventeenth century. The author, perhaps Cornelis Jacobsz van Heenvliet, gives the impression that he writes from personal experience and that he does not believe older tales without having seen it with his own eyes. This extensive manuscript may be summarised as follows.

Almost any bird and mammal species could be hunted. Large birds, however, such as cranes (Grus grus), grey heron (Ardea cineria), night heron (Nycticorax nycticorax), spoonbill (Platalea leucorodia), shelduck (Tadorna tadorna) and cormorant (Phalacrocorax carbo) were considered 'noble game' and could only be hunted by the upper classes with falcons. But the eggs and young of most species, including those listed above, could be collected, often commercially. Only eggs of swans were not to be taken.

This situation probably lasted until the end of the eighteenth century. After the French revolutionary armies occupied The Netherlands in 1795, all feudal rights were abolished. After the French occupation, ending in 1813, these feudal rights were not restored and all birds and mammals continued to be free for all. Especially in the Wadden Sea, this was probably a period with a heavy exploitation pressure on birds. In the first place, there were hardly any rules governing exploitation. Second, maintenance of any rules in the vast Wadden Sea and its isolated islands would have been very difficult. Third, a large part of the population of the barrier islands faced a period of extreme poverty, so any addition to the diet would have been welcome. This translated to the widespread collection of eggs and young birds, catching of geese and shorebirds with nets, and catching ducks in duck decoys.
Swennen (1982) describes the situation with regard to egg collection in the Dutch Wadden Sea in the nineteenth and earlier centuries. Eggs of all bird species could be collected everywhere without restrictions, unless a particular breeding colony was considered private property. Such a colony could be exploited commercially by collecting the eggs early in the season and afterwards protecting the breeding birds. Such exploited colonies of gulls and terns did occur at Rottumeroog and at Eijerland (now part of Texel). The Eijerland colony in the eighteenth century annually sent 30,000 eggs to Amsterdam to be used by the local bakers. According to Swennen (1982, see also Wolff 2000a) this heavy egg collecting led to the extirpation of several bird species. An 'experimental' confirmation of this hypothesis is provided by the return of eider duck Somateria mollissima, common gull L. canus and lesser blackbacked gull Larus fuscus as breeding birds in the twentieth century (Swennen 1982). In that period, large parts of the barrier islands were placed under nature protection (Gorter 1986).

LANCEWAD (2001) identifies 142 duck decoys around the Dutch Wadden Sea. Of these, 29 still exist, 13 are derelict and 100 have disappeared. The latter ones may be identified on old maps or in historical documents. A duck decoy is a pond usually surrounded by some woodland; most decoys have four to six catching ditches running from the pond into the woodland. The decoy man lures wild ducks into the ditches and once they arrive at the end of the ditch, they cannot escape. Depending on the topographical situation, a duck decoy catches various species of ducks in different proportions. The main species for decoys around the Wadden Sea are mallards (Anas platyrhynchos), teal (A. crecca), wigeon (A. penelope) and pintail (A. acuta). Depending on the weather, the experience of the decoy man, and the topographical situation of a decoy 1,000-12,000 ducks were caught annually in each decoy (Haverschmidt 1931; Van der Heide and Lebret 1944). This means that the total catch of all decoys around the Wadden Sea might have been some 100,000-200,000 ducks per year.

\section{Marine mammals}

There is no information that small cetaceans, such as harbour porpoises (Phocoena phocoena) and bottlenose dolphins (Tursiops truncatus), have ever been hunted in the Dutch Wadden Sea. Probably the topography was not suitable for hunting. Porpoises have been hunted elsewhere in NW Europe (De Smet 1976) but I do not believe that this will have affected the population in the Dutch Wadden Sea.

This is different for seals. Harbour seals (Phoca vitulina) were hunted in the Dutch Wadden Sea until 1962 (Reijnders 1992). Especially in the period between the Second World War and 1962, when almost all juvenile seals were killed for their pelts, hunting resulted in a strong decline of the population. However, Reijn- 
ders (1992) makes a plausible argument that a slow decline due to hunting had already occurred over a long period. After 1962 the Dutch harbour seal population faced a negative reproductive situation due to PCB pollution; an initial recovery of the population after the closure of hunting soon changed into a further decline. Only in the 1980s, when the PCB pollution decreased and hunting remained prohibited, could the seal population increase again (Reijnders 1992).

Grey seals (Halichoerus grypus) were, until recently, absent from the Dutch Wadden Sea. However, subfossil remains of grey seals are more common in The Netherlands than those of harbour seals (Clason 1967) and have been found in at least eight different archaeological excavations in the Wadden Sea area, adjacent to NorthHolland and elsewhere in The Netherlands. The finds range from about 2000 B.C. to the early Middle Ages (Van Giffen 1914; Clason 1967, 1977, 1988; Zeiler 1997). Because its pups stay on dry land for several weeks, these will have been an easy prey, and hence I assume that the grey seal in the Dutch Wadden Sea area became an early victim of overexploitation (Reijnders 1978). This provides a likely explanation for the absence of grey seals from the Wadden Sea from the Middle Ages until quite recently (Reijnders et al. 1995). In the second half of the twentieth century, the grey seal returned to the Dutch Wadden Sea. This was probably a result of a combination of three developments. In the first place, the grey seal had got protection in the UK, resulting in a very strong increase of the British population leading to a spill-over to the other side of the North Sea. Second, British pups washing ashore on the Dutch coast were kept alive by Dutch seal rehabilitation stations. Finally, the seals were offered protection from disturbance by the statutory protection of the Dutch Wadden Sea since 1980 (Wolff, unpublished data; Reijnders et al. 1995).

\section{Discussion and conclusions}

The picture emerging from the previous paragraphs is a picture of unrestricted exploitation of living resources in the Dutch Wadden Sea area. In the twentieth and twenty-first centuries, an increasing body of regulations determines what species can be exploited and to what extent. For some species, this means that they are protected (birds, mammals), for others exploitation will have remained at a high level (fish). Therefore, the twentieth century is a biased indicator of the importance of exploitation of living resources, because of these new regulations.

We should instead look at the nineteenth and earlier centuries to obtain a better picture of the importance of exploitation. This picture shows that every species could be exploited provided that there existed a market for the products and given that the hunter or fisher could realize a positive balance between benefits and costs. This costbenefit analysis will not have been a formal analysis; it will unconsciously have been made by the hunters and fishermen. But, nevertheless, it determined that some species were not hunted or fished (e.g. harbour porpoises) and that others were fished to near-extinction (e.g. European flat oysters). The benefits, however, depended on the market. In many cases, the small and usually poor communities around the Wadden Sea will not have been much of a market. But in relation to exploitation of the Dutch Wadden Sea it is often mentioned (e.g. Van der Vlis 1975; Van der Heide and Lebret 1944; Mast 2003) that yields were sold in Amsterdam and other large cities. It is also not uncommon to read that game or fish were exported: Germany and England are mentioned repeatedly. A recent example is the cockle fishery dependent on the Spanish market. At the same time, markets are continuously changing due to, for example, war conditions, economic depression, changing preferences and the construction of railways.

The market, in practice the price which could be obtained for a particular catch, also was the cause of switching between alternative fisheries, or between fisheries and farming in the course of the year. This led to fisheries in which many different types of living resources were exploited. In the course of the year, fishermen could switch from collecting oysters, to fishing smelt, herring or flatfish, and then again to harvesting eelgrass, for example. This opportunistic behaviour of these artisan fishermen is largely a phenomenon of the past. Nowadays, fishers tend to be more specialised. Of the many former fisheries, only those for blue mussels, cockles, shrimp and flatfish are still of any importance.

Bycatch and damage to other organisms because of fishing or hunting are seldom mentioned in the literature about past practices. One explanation is that what we consider to be bycatch nowadays was probably largely catch in former centuries. Damage of other organisms due to fishing gear has been mentioned for centuries, but I assume that its importance has greatly increased after ever stronger engines were built into fishing vessels.

In an earlier paper (Wolff 2000a) I concluded that overexploitation had played a part in the extirpation of about 17 species form the Dutch Wadden Sea. It should be noted that this concerned mainly large and slowly reproducing species, i.e. marine mammals, large birds and the larger species of fish.

In this paper, I have examined former and present forms of exploitation of living resources in the Dutch Wadden Sea to see if exploitation indeed may have been a cause of the extirpation of species. The first conclusion is that a large variety of living resources has been, or still is, exploited. This means that for any species which has disappeared from the Wadden Sea, exploitation should be considered as a possible cause. Second, it is clear that several species were exploited without negative effects on populations. This holds, for example, for eelgrass, lugworms and brown shrimps. Third, it is shown that many exploited species did decline in numbers. Although in many cases a causal relationship remains to be demonstrated, the coincidence of exploitation and decline suggests strongly that exploitation played at least a part 
in the decline. Permanent or temporal declines have been shown to occur for blue mussels, cockles, most fish species, most species of coastal birds and two species of seals. However, population ecology has shown that a lower population level does not necessarily mean overexploitation. A sustainable exploitation is very well possible at a reduced population level. My fourth conclusion, however, is that apparently for several species exploitation was too strong to be sustained. This is suggested for the European flat oyster, for several large species of fish (e.g. thornback ray, sting ray and sturgeon), some species of coastal birds (e.g. eider duck) and for the grey seal.

That overexploitation really was the case of disappearance of species is proved by the 'experiment' of protecting breeding areas early in the twentieth century. Swennen (1982) showed that soon after protective measures were installed, eider ducks, common gulls and lesser black-backed gulls returned as breeding birds in the Dutch Wadden Sea area. The return to the Dutch Wadden Sea of the grey seal is another example (Reijnders et al. 1995).

Finally, I want to stress that exploitation of almost all living resources as described in the past for the Dutch Wadden Sea is not a peculiarity of this area. Similar areas nearby, such as the German Wadden Sea and the estuaries in the SW Netherlands will have experienced a similar exploitation pressure in the past. In the second half of the twentieth century one could still observe similar situations on the French coast (Wolff, unpublished observations). At present, this type of exploitation pressure still occurs in several developing countries, such as Indonesia and the Philippines (Wolff, unpublished observations).

\section{References}

Anonymous (1636) Jacht-Bedrijff. Manuscript in the Royal Library at 's-Gravenhage

Beukema JJ (1976) Biomass and species richness of macro-benthic animals living on the tidal flats of the Dutch Wadden Sea. Neth J Sea Res 10:236-261

Brinkhuizen DC (1988) Vis en visvangst bij de terpbewoners. In: Bierma M, Clason AT, Kramer E, de Langen GJ (eds) Terpen en wierden in het Fries-Groningse kustgebied. Wolters-Noordhoff/Forsten, Groningen, The Netherlands, pp 226-233

Brinkhuizen DC (1989) Ichthyo-archeologisch onderzoek: methoden en toepassing aan de hand van Romeins vismateriaal uit Velsen (Nederland). PhD thesis, University of Groningen, p 312

Clason AT (1967) Animal and man in Holland's past. An investigation of the animal world surrounding man in prehistoric and early historical times in the provinces of North and South Holland. PhD thesis, Rijksuniversiteit Groningen

Clason AT (1977) Jacht en veeteelt van prehistorie tot Middeleeuwen. Fibula-Van Dishoeck, Haarlem, The Netherlands

Clason AT (1988) De grijze zeehond Halichoerus grypus (Fabricius, 1791). In: Bierma M, Clason AT, Kramer E, de Langen GJ (eds) Terpen en wierden in het Fries-Groningse kustgebied. Wolters-Noordhoff/Forsten, Groningen, pp 234-240

Coenen A (1585) Het Walvisboek. Walvissen en andere zeewezens beschreven door Adriaen Coenen. Published in 2003 by Walburg Pers, Zutphen, The Netherlands
De Groot SJ (1990a) Herstel van riviertrekvissen in de Rijn een realiteit? 1. De Atlantische zalm (Salmo salar). De Levende Natuur 91:82-88

De Groot SJ (1990b) Herstel van riviertrekvissen in de Rijn een realiteit? 3. De grote en kleine maraene (Coregonus lavaretus en C. albula). De Levende Natuur 91:215-219

De Groot SJ (1992a) Herstel van riviertrekvissen in de Rijn een realiteit? 6. De steur (Acipenser sturio). De Levende Natuur 93:14-18

De Groot SJ (1992b) Herstel van riviertrekvissen in de Rijn een realiteit? 7. De elft (Alosa alosa). De Levende Natuur 93:56-60

De Jonge VN, Essink K, Boddeke R (1993) The Dutch Wadden Sea: a changed ecosystem. Hydrobiologia 265:45-71

De Smet WMA (1976) Evidence of whaling in the North Sea and the English Channel during the Middle Ages. In: Scientific consultation on marine mammals, Bergen, Norway, 31 August9 September 1976, p 8

De Vooys GCN, Witte JIJ, Dapper R, Van der Meer JM, Van der Veer HW (1991) Lange-termijn veranderingen in zeldzame vissoorten op het Nederlands continentaal plat van de Noordzee. Neth Inst Sea Res - NIOZ-Rapport 1991-6, p 81

De Ruyter de Wildt JC (1928) Over de bemestingswaarde van zeesterren en ricinusmeel. Landbouwkundig Tijdschrift 40(477):279-285

Dijkema R (1997) Molluscan fisheries and culture in the Netherlands. U.S. Department of Commerce, NOAA Technical Report NMFS 129:115-135

Dijksterhuis J (1977) Revolutie in de wadpierenspitterij en de mogelijke gevolgen. Student report, Rijksinstituut voor Natuurbeheer, Texel

Dijt MD (1961) Texelse oesters, aantekeningen over opkomst en verval. Visserijnieuws 14:99-102

Engel H (1932) Echinodermata. Fauna van Nederland 6. A.W. Sijthoff's Uitgeversmij, Leiden, The Netherlands

Ens BJ (2003) What we know and what we should know about mollusc fisheries and aquacultures in the Wadden Sea. In: Wolff WJ, Essink K, Kellermann A, van Leeuwe MA (eds) Proceedings of the 10th international scientific Wadden Sea symposium, Groningen, The Netherlands, 31 October -3 November 2000 , pp 121-146

Ens BJ, Smaal AC, de Vlas J (2004) The effects of shellfish fishery on the ecosystems of the Dutch Wadden Sea and Oosterschelde. Final report on the second phase of the scientific evaluation of the Dutch shellfish fishery policy (EVA II). Alterra-rapport 1011

Gorter HP (1986) Ruimte voor de natuur. 80 jaar bezig voor de natuur van de toekomst. Vereniging tot Behoud van Natuurmonumenten in Nederland, "s-Graveland, The Netherlands

Haverschmidt F (1931) Vangstcijfers van eenige Nederlandsche eendenkooien. Ardea 20:152-169

Havinga B (1954) Vissen. In: de Beaufort LF (ed) Veranderingen in de flora en fauna van de Zuiderzee (thans IJsselmeer) na de afsluiting in 1932. Ned Dierk Ver, Den Helder, The Netherlands, pp 253-267

Holthuis LB (1950) Decapoda A. Natantia, Macrura Reptantia, Anomura en Stomatopoda. Fauna van Nederland 15:1-166

Kirchhoff J (2000) Fischfang auf dem Wattengrund. Verlag H. Risius, Weener (Ems), The Netherlands

LANCEWAD (2001) Waddenland. Het landschap en cultureel erfgoed in de Waddenzeeregio. Ministerie van Landbouw, Natuurbeher en Visserij, Groningen / Uitgeverij Noordboek, Leeuwarden, The Netherlands

Mast G (2003) De eendenkooi van Ternaard. Report Directie Noord van het Ministerie Van Landbouw, Natuurbeheer en Visserij

Oudemans CAJA, Conrad JFW, Maats P, Bouricius L (1870) Verslag der Staatscommissie inzake de wiermaayerij. Verslag aan den Koning over de Openbare Werken in het jaar 1869. Van Weelden en Mingelen, Den Haag, pp 199-231

Postuma KH, Rauck G (1979) The fishery in the Wadden Sea. In: Dankers N, Wolff WJ, Zijlstra JJ (eds) Fishes and fisheries of the Wadden Sea. Balkema, Rotterdam, The Netherlands, pp $139-157$ 
Reijnders PJH (1978) De Grijze zeehond in het Waddengebied. Waddenbulletin 13:500-502

Reijnders PJH (1992) Retrospective population analysis and related future management perspectives for the harbour seal (Phoca vitulina) in the Wadden Sea. Neth Inst Sea Res Publ Ser 20:1-5

Reijnders PJH, van Dijk J, Kuiper D (1995) Recolonization of the Dutch Wadden Sea by the Grey seal Halichoerus grypus. Biol Cons 71:231-236

Schaper A (1962) De IJsselmeervisserij. PhD thesis, University of Amsterdam, p 164

Swennen C (1982) De vogels langs onze kust. In: Wolff WJ (ed) Wadden, Duinen, Delta. Pudoc, Wageningen, The Netherlands, pp 78-100

Van Giffen AE (1913) Die Fauna der Wurten, erster Teil. PhD thesis, University of Groningen, The Netherlands, p 166

Van Giffen AE (1914) Die Fauna der Wurten. Tijdschrift der Nederlandsche Dierkundige Vereeniging 13(2):1-166

Van Katwijk MM (2003) Reintroduction of eelgrass (Zostera marina) in the Dutch Wadden Sea: a research overview and management vision. In: Wolff WJ, Essink K, Kellermann A, van Leeuwe MA (eds) Proceedings of the 10th international scientific Wadden Sea symposium, Groningen, The Netherlands, 31 October - 3 November 2000, pp 173-195

Van Benthem Jutting T (1943) Mollusca C. Lamellibranchia. Fauna van Nederland 12:1-477

Van den Heiligenberg T (1987) Effects of mechanical and manual harvesting of lugworms Arenicola marina, on the benthic fauna of tidal flats in the Dutch Wadden Sea. Biol Cons 39:165-177

Van der Heide GD, Lebret T (1944) Achter de schermen. Een boek over eendenkooien. Kinheim Uitgeverij, Heiloo, The Netherlands

Van der Vlis JA (1975) tLant van Texsel. Een geschiedschrijving. Langeveld \& De Rooy, Den Burg, The Netherlands, p 528

Vervoort W (1946) Hydrozoa, A. Hydropoliepen. Fauna van Nederland 14. A.W. Sijthoff's Uitgeversmij, Leiden, The Netherlands

Weijdt LJ (1980) Oude en nieuwe dijken. In: Texel en de zee. Een strijd van eeuwen. Texelse Museum vereniging, Texel, The Netherlands, pp 73-97

Wolff WJ (1992) The end of a tradition. 1000 years of embankment and reclamation of wetlands in The Netherlands. Ambio $21: 287-291$

Wolff WJ (2000a) Causes of extirpations in the Wadden Sea, an estuarine area in the Netherlands. Cons Biol 14:876-885

Wolff WJ (2000b) The south-eastern North Sea: losses of vertebrate fauna during the past 2000 years. Biol Cons 95:209-217

Zeiler JT (1997) Hunting, fowling and stock-breeding at neolithic sites in the western and central Netherlands. PhD Thesis, University of Groningen, The Netherlands, p 211

Zijlstra JJ (1979) The function of the Wadden Sea for the members of its fish fauna. In: Dankers N, Wolff WJ, Zijlstra JJ (eds) Fishes and fisheries of the Wadden Sea. Balkema, Rotterdam, pp 20-25 